\title{
Halogen-substituted ureas for anion binding: solid state and solution
}

studies.

Arianna Casula, ${ }^{a}$ Marco Fornasier, ${ }^{a}$ Riccardo Montis, ${ }^{* a, b}$ Alexandre

Bettoschi, ${ }^{a}$ Stephen P. Argent, ${ }^{c}$ Alexander J. Blake, ${ }^{c}$ Vito Lippolis, ${ }^{a}$ Laura

Marongiu, ${ }^{a}$ Giacomo Picci, ${ }^{\mathrm{a}}$ Jeremiah P. Tidey, ${ }^{\mathrm{c}}$ Claudia Caltagirone. ${ }^{* a}$

${ }^{a}$ Dipartimento di Scienze Chimiche e Geologiche, Università degli Studi di Cagliari,

S.S. 554 Bivio per Sestu, 09042 Monserrato (CA), Italy. ccaltagirone@ unica.it

${ }^{b}$ Present address: Department of Materials, Imperial College London, South

Kensington Campus, London, SW7 2AZ, UK, r.montis@imperial.ac.uk

${ }^{c}$ School of Chemistry, University of Nottingham, University Park, Nottingham NG7

$2 R D, U K$ 


\section{Halogen-substituted ureas for anion binding: solid state and solution studies.}

Herein, we report the synthesis and the anion binding properties of a family of $N, N^{\prime}$-diphenylureas $\mathbf{L}_{\mathbf{1}}-\mathbf{L}_{\mathbf{1 5}}$, bearing on the aromatic ring(s) halogens (chlorine and iodine) and/or nitro or trifluoromethyl electron-withdrawing groups. The analysis of the crystal structures obtained from single crystal X-ray diffraction experiments shows that self-assembled chains or tapes connected via $\mathrm{N}-\mathrm{H} \cdots \mathrm{O}$ hydrogen bonds are the most commonly adopted arrangements for this type of molecules in the crystal lattice. In the presence of anion guests or solvent molecules with competing hydrogen bond donors and acceptors, other supramolecular arrangements can be observed. Solution studies conducted in DMSO- $d_{6} / 0.5 \% \mathrm{H}_{2} \mathrm{O}$ by means of ${ }^{1} \mathrm{H}-\mathrm{NMR}$ titrations show the formation of $1: 1$ adducts with all receptors. The different observed affinities of the receptors for the anion guests were rationalised in terms of steric hindrance of the substituents on the phenyl rings and their electron-withdrawing properties.

Keywords: anion binding, phenylurea

\section{Introduction}

The development of synthetic receptors for anion binding, sensing, catalysis and transport is one of the most active area of Supramolecular Chemistry. ${ }^{1}$ In particular, the design and synthesis of neutral receptors capable of recognizing anions in competitive solvent mixture, and possibly in water, is rather challenging because of competition issues. Urea and thiourea-based receptors have been widely studied for anion binding because of their synthetic accessibility and also their ability to interact through strong, directional hydrogen bonds. ${ }^{2}$ Recently, selenoureas have also been proposed for anion binding and sensing. ${ }^{3}$ The urea (or thiourea) moiety bearing two N-H groups can bind the anionic guest (in particular spherical anions such as halides) as a monodentate 
ligand with a single acceptor atom to yield a six-membered chelate ring. They may also bind as a bidentate ligand with two adjacent oxygen atoms in an oxyanion to form an eight-membered chelate ring. Among the different type of urea derivatives developed over recent years, $N, N^{\prime}$-diphenylurea represents one of the simplest and most popular receptor for anion binding. ${ }^{4}$

In the solid state, this class of compounds have been extensively investigated. ${ }^{5} N, N^{\prime}-$ diphenylurea forms robust and predictable self-assembled chains or tapes connected via $\mathrm{N}-\mathrm{H} \cdots \mathrm{O}$ hydrogen bonds. Etter et al. demonstrated that the presence of electronwithdrawing groups in diaryl urea decreases the tendency to form self-assembled 1-D chains. ${ }^{6}$ This is due to the increased acidity of the ortho aromatic $\mathrm{C}-\mathrm{H}$ that forms intramolecular hydrogen bonds with the urea $\mathrm{C}=\mathrm{O}$, reducing its ability to interact with adjacent urea NHs. Therefore, the disruption of these 1-D chains is often associated to a coplanar conformation of the phenyl rings with respect to the urea plane.

A similar behaviour was described by Nangia and collaborators who investigated a family of substituted $N$-X-phenyl- $N$--p-nitrophenyl urea compounds $(\mathrm{X}=\mathrm{H}, \mathrm{F}, \mathrm{Cl}, \mathrm{Br}, \mathrm{I}$, $\left.\mathrm{CN}, \mathrm{C} \equiv \mathrm{CH}, \mathrm{CONH}_{2}, \mathrm{COCH}_{3}, \mathrm{OH}, \mathrm{Me}\right){ }^{7}$ The results allowed the authors to classify the family of structures into two main categories: (i) urea tapes structures, formed by classic urea $\mathrm{N}-\mathrm{H} \cdots \mathrm{O}$ hydrogen bonds, in which phenyl rings adopt a twisted conformation with respect to the urea plane, and (ii) non-urea tape structures in which the phenyl groups adopt a coplanar conformation and the classical urea $\mathrm{N}-\mathrm{H} \cdots \mathrm{O}$ hydrogen bonds are replaced by interactions with $\mathrm{NO}_{2}$ groups or solvent molecules.

Recently, Gale, Coles, et al. described a systematic structural analysis on a series of urea-based anion receptor complexes including high-resolution, experimental an electron density study. ${ }^{8}$ The authors demonstrated that by systematically altering the position and the number of electron-withdrawing nitro groups in the 1,3-diphenylurea 
scaffold, it is possible to modulate the strength of the interaction between the receptor and anion. By geometric analysis of the hydrogen bonding interactions they also suggested that moving from meta to para to 3,5-dinitro substitution the hydrogen bond strength increases.

In recent years, beside hydrogen bond-, also halogen bond- based receptors have been developed for anion binding. The term "halogen bonding (XB)" was officially defined by IUPAC in 2013 as a non-covalent interaction between a halogen bond donor R-X (where $\mathrm{X}$ is a halogen atom with an electrophilic region and a $\mathrm{R}$ is any organic group) and a halogen bond acceptor $\mathrm{Y}$ (where $\mathrm{Y}$ is a nucleophilic molecular entity). ${ }^{9}$ Halogen bonds RX $\cdots$ Y are almost linear and they have an energy comparable with the hydrogen bonds $\left(5-180 \mathrm{~kJ} \mathrm{~mol}^{-1}\right)$.

Taylor et al. have reported a family of urea based receptors for anion recognition that contain iodoperfluoro-arene groups. ${ }^{10}$ These systems are able to interact with anions via both hydrogen and halogen bonds.

An example of simple symmetric $N, N^{\prime}$-diphenylurea receptors para substituted with halogens and able to bind anions forming both hydrogen and halogen bonds in solution and in the solid state was reported by Das et al. ${ }^{11}$

Inspired by these results we decided to synthesize a new family of simple asymmetric $N, N^{\prime}$-diphenylurea receptors $\mathbf{L}_{\mathbf{1}}-\mathbf{L}_{15}$ for anion recognition. These receptors are substituted on one of the phenyl ring with iodine and chlorine in various position (ortho and para for chlorine and ortho for iodine), and with nitro or a trifluoromethyl moiety on the other (Figure 1).

These different combinations of substituents on the two phenyl groups were chosen in order to evaluate the effect of electron-withdrawing groups and halogens on the anion binding ability. Receptors $\mathbf{L}_{\mathbf{1}}, \mathbf{L}_{\mathbf{4}}, \mathbf{L}_{\mathbf{7}}, \mathbf{L}_{\mathbf{1 0}}$, and $\mathbf{L}_{\mathbf{1 3}}$, whose synthesis was already reported 
in the literature, ${ }^{6 b, 12}$ were used as control molecules for each series of receptors with the same substituents. We tested receptors $\mathbf{L}_{\mathbf{1}}-\mathbf{L}_{\mathbf{1 5}}$ with a set of anions of different geometries [(Y-shape $\left(\mathrm{AcO}^{-}\right.$and $\left.\mathrm{BzO}^{-}\right)$, spherical $\left(\mathrm{Cl}^{-}\right.$and $\left.\mathrm{F}^{-}\right)$and tetrahedral $\left.\left(\mathrm{H}_{2} \mathrm{PO}_{4}^{-}\right)\right]$ by means of ${ }^{1} \mathrm{H}-\mathrm{NMR}$ spectroscopy and, where possible, single crystal X-ray diffraction.<smiles>O=C(Nc1ccccc1)Nc1ccccc1</smiles>

$\mathbf{L}_{1}$<smiles>O=C(Nc1ccccc1)Nc1ccccc1[N+](=O)[O-]</smiles>

$\mathbf{L}_{4}$<smiles>O=C(Nc1ccccc1)Nc1cccc([N+](=O)[O-])c1</smiles>

$L_{7}$<smiles>O=C(Nc1ccccc1)Nc1ccc([N+](=O)[O-])cc1</smiles><smiles>O=C(Nc1ccccc1)Nc1ccc(C(F)(F)F)cc1</smiles><smiles>O=C(Nc1ccccc1)Nc1ccc(Cl)cc1Cl</smiles>

$\mathbf{L}_{2}$<smiles>O=C(Nc1ccc(Cl)cc1Cl)Nc1ccccc1[N+](=O)[O-]</smiles>

$\mathbf{L}_{5}$<smiles>O=C(Nc1cccc([N+](=O)[O-])c1)Nc1ccc(Cl)cc1Cl</smiles>

$L_{8}$<smiles>O=C(Nc1ccc([N+](=O)[O-])cc1)Nc1ccc(Cl)cc1Cl</smiles><smiles>O=C(Nc1ccc(C(F)(F)F)cc1)Nc1ccc(Cl)cc1Cl</smiles>

$L_{14}$<smiles>O=C(Nc1ccccc1)Nc1ccccc1I</smiles>

$\mathbf{L}_{3}$<smiles>O=C(Nc1ccccc1I)Nc1ccccc1[N+](=O)[O-]</smiles>

$L_{6}$<smiles>O=C(Nc1cccc([N+](=O)[O-])c1)Nc1ccccc1I</smiles>

$L_{9}$<smiles>O=C(Nc1ccc([N+](=O)[O-])cc1)Nc1ccccc1I</smiles><smiles>O=C(Nc1ccc(C(F)(F)F)cc1)Nc1ccccc1I</smiles>

$L_{15}$

Figure 1 Receptors L1-L 15

\section{Results and discussion}

\section{Synthesis}

Receptors $\mathbf{L}_{\mathbf{1}}-\mathbf{L}_{\mathbf{1 5}}$ were designed and successfully synthesized according to Scheme 1-3.

The synthesis are based on the simple nucleophilic addition of an isocyanate (phenyl isocyanate, nitro-phenyl isocyanate or trifluoromethyl-phenyl isocyanate for receptors $\mathbf{L}_{1}-\mathbf{L}_{3}, \mathbf{L}_{4}-\mathbf{L}_{12}$ and $\mathbf{L}_{13}-\mathbf{L}_{15}$ respectively) and the appropriate aniline. As mentioned in the 
introduction, the synthesis of receptors $\mathbf{L}_{\mathbf{1}}, \mathbf{L}_{\mathbf{4}}, \mathbf{L}_{\mathbf{7}}, \mathbf{L}_{\mathbf{1 0}}$, and $\mathbf{L}_{\mathbf{1 3}}$, had been reported before. $^{6 \mathrm{~b}, 12}$ After two hours of reflux in DCM, all the products were obtained as pure solids by precipitation, in a widly variable yields depending on the substituents introduced in the systems (20-96\%).

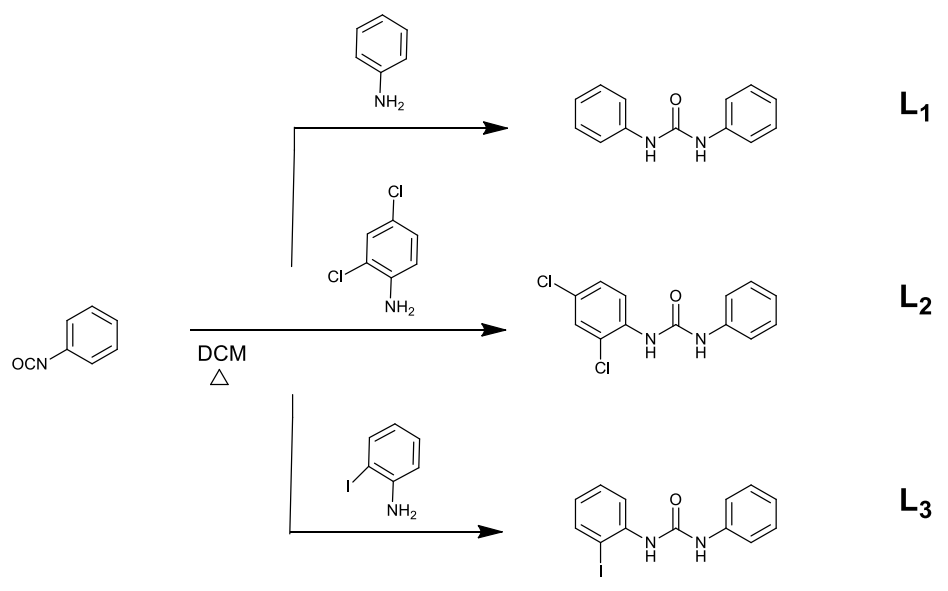

Scheme 1 Reaction scheme adopted for the synthesis of $\mathbf{L}_{1}, \mathbf{L}_{2}$, and $\mathbf{L} 3$.

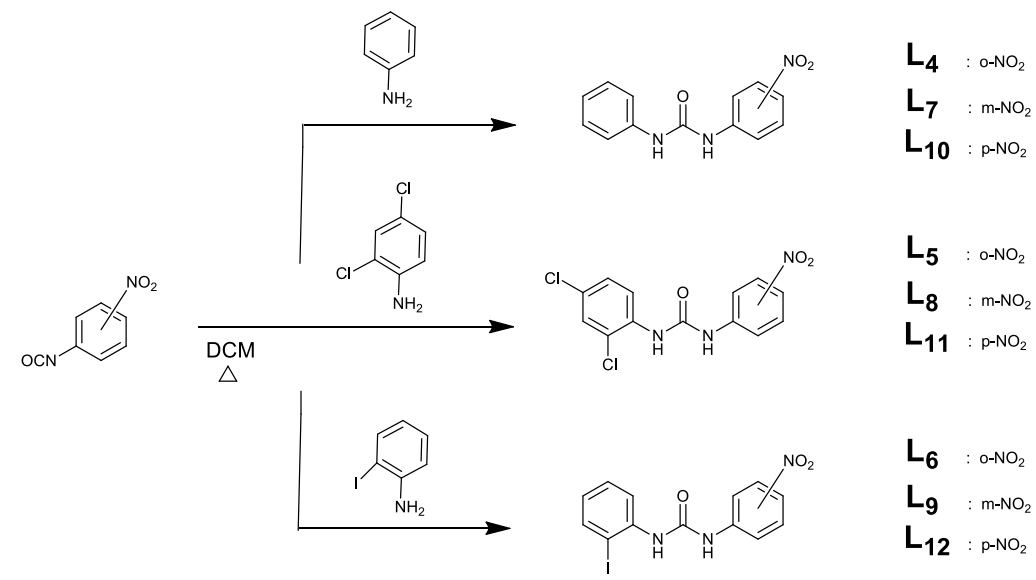

Scheme 2 Reaction scheme adopted for the synthesis of $\mathbf{L 4 - L 1 2 . ~}$ 


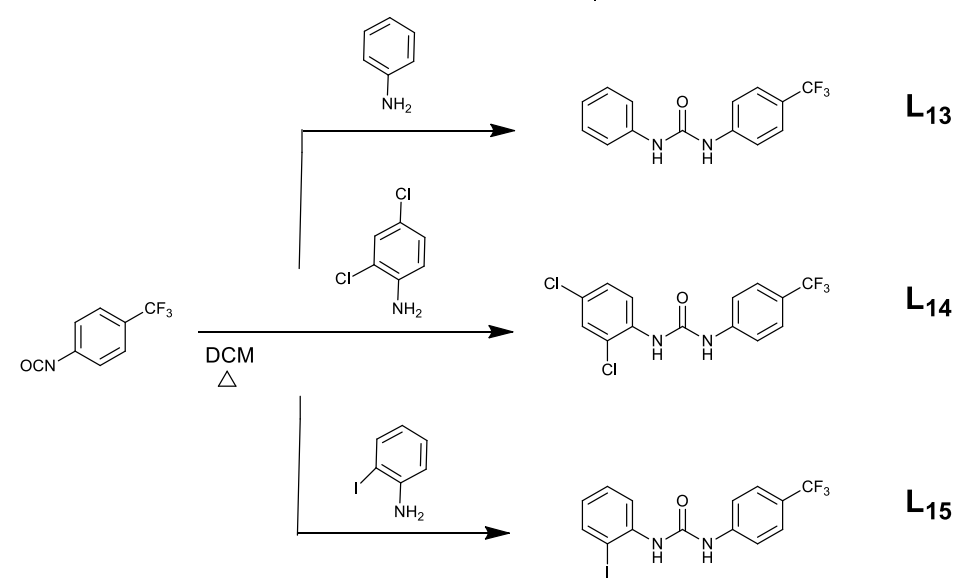

Scheme 3 Reaction scheme adopted for the synthesis of $\mathbf{L 1 3}, \mathbf{L} \mathbf{1 4}$, and $\mathbf{L} 15$.

\section{Single Crystal X-Ray Diffraction}

To investigate binding properties in solid state of $\mathbf{L}_{\mathbf{1}}-\mathbf{L}_{\mathbf{1 5}}$, all the receptors were crystallised by slow evaporation from various solvents and in the presence of different anion guests. Surprisingly, we could isolate crystals suitable for single crystal X-ray diffraction only for the adduct $\mathbf{L}_{6}$-tetrabutylammonium benzoate ( $\left.\mathbf{L 6}-\mathbf{B z O}^{-}\right)$. Crystallisations of free receptors $\mathbf{L}_{\mathbf{1}}-\mathbf{L}_{\mathbf{1 5}}$ produced single crystals only for $\mathbf{L}_{\mathbf{1}}, \mathbf{L}_{\mathbf{5}}, \mathbf{L}_{\mathbf{8}}$, L14, and $\mathbf{L}_{15}$. In the case of receptor $\mathbf{L}_{2}$, crystallisations in presence of tetrabutylammonium fluoride or tetrabutylammonium iodide produced two distinct polymorphic phases, designated $\mathbf{L}_{2} \boldsymbol{\alpha}$ and $\mathbf{L}_{2} \boldsymbol{\beta}$, respectively. $\mathbf{L}_{\mathbf{8}}$ and $\mathbf{L}_{\mathbf{1 1}}$ crystallised as solvate forms, a DMSO solvate $\mathbf{L} 8 \bullet \mathrm{DMSO}$ and a mixed solvate $\mathbf{L} 11 \bullet 2 \mathrm{DMSO} \bullet \mathrm{DMF}$, respectively.

Table 1. Unit cell parameters for the crystal structures of $\mathbf{L}_{\mathbf{1}}, \mathbf{L}_{\mathbf{2}} \alpha, \mathbf{L}_{\mathbf{2}} \boldsymbol{\beta}, \mathbf{L} \mathbf{5}, \mathbf{L}_{\mathbf{8}}, \mathbf{L}_{\mathbf{1 4}}, \mathbf{L}_{15}$, $\mathbf{L 8} \bullet \mathrm{DMSO}, \mathbf{L 1 1} \bullet 2 \mathrm{DMSO} \bullet \mathrm{DMF}$, and $\mathbf{L 6}-\mathbf{B z O}$.

\begin{tabular}{|c|c|c|c|c|c|}
\hline & $\mathrm{L}_{1}$ & $\mathrm{~L}_{2} \alpha$ & $\mathrm{L}_{2} \beta$ & $\mathrm{L}_{5}$ & $\mathrm{~L}_{8}$ \\
& $\mathrm{CCDC} 1561823$ & $\mathrm{CCDC1561826}$ & $\mathrm{CCDC1562645}$ & $\mathrm{CCDC1561828}$ & $\mathrm{CCDC1561825}$ \\
\hline
\end{tabular}




\begin{tabular}{|c|c|c|c|c|c|}
\hline Formula & $\mathrm{C}_{13} \mathrm{H}_{12} \mathrm{~N}_{2} \mathrm{O}$ & $\mathrm{C}_{13} \mathrm{H}_{10} \mathrm{~N}_{2} \mathrm{OCl}_{2}$ & $\mathrm{C}_{13} \mathrm{H}_{10} \mathrm{~N}_{2} \mathrm{OCl}_{2}$ & $\mathrm{C}_{13} \mathrm{H}_{9} \mathrm{~N}_{3} \mathrm{O}_{3} \mathrm{Cl}_{2}$ & $\mathrm{C}_{13} \mathrm{H}_{9} \mathrm{~N}_{3} \mathrm{O}_{3} \mathrm{Cl}_{2}$ \\
\hline FW & 212.25 & 281.13 & 281.13 & 326.13 & 326.13 \\
\hline $\begin{array}{l}\text { Crystal } \\
\text { System }\end{array}$ & orthorhombic & triclinic & triclinic & monoclinic & orthorhombic \\
\hline $\begin{array}{l}\text { Space } \\
\text { Group }\end{array}$ & Pna $_{1}$ & $P-1$ & $P-1$ & $P 2_{1} / \mathrm{n}$ & $P$ Pna $2_{1}$ \\
\hline $\mathbf{a} / \AA$ & $9.0641(3)$ & $4.6123(14)$ & $4.5612(3)$ & $4.6027(7)$ & $42.4563(6)$ \\
\hline $\mathbf{b} / \AA$ & $10.3509(3)$ & $11.9420(5$ & $11.5202(11)$ & $48.5814(8)$ & $6.5738(1)$ \\
\hline $\mathrm{c} / \AA \AA \AA$ & $11.7422(3)$ & $22.8508(7)$ & $12.1448(9)$ & $5.9207(14)$ & $4.7887(1)$ \\
\hline$\alpha / /^{\circ}$ & 90 & $93.005(3)$ & $103.972(7)$ & 90 & 90 \\
\hline$\beta / /^{\circ}$ & 90 & $92.645(3)$ & $94.249(5)$ & $95.7193(17)$ & 90 \\
\hline$\gamma /{ }^{\circ}$ & 90 & $97.764(3)$ & $95.458(6)$ & 90 & 90 \\
\hline$V / \AA^{3}$ & $1101.68(5)$ & $1243.57(8)$ & $613.35(8)$ & $1317.32(4)$ & $1336.52(4)$ \\
\hline$T / \mathbf{K}$ & $120(2)$ & 293(2) & $120(2)$ & $120(2)$ & $120(2)$ \\
\hline$Z$ & 4 & 4 & 2 & 4 & 4 \\
\hline & $\begin{array}{c}\mathrm{L}_{14} \\
\text { CCDC 1562644 }\end{array}$ & $\begin{array}{c}\mathrm{L}_{15} \\
\text { CCDC } 1561819\end{array}$ & $\begin{array}{c}\text { Ls॰DMSO } \\
\text { CCDC 1561821 }\end{array}$ & $\begin{array}{l}\text { L11・2DMSO•DMF } \\
\text { CCDC } 1561822\end{array}$ & $\begin{array}{c}\mathrm{L}_{6-\mathrm{BzO}^{-}} \\
\mathrm{CCDC1561827}\end{array}$ \\
\hline Formula & $\mathrm{C}_{14} \mathrm{H}_{9} \mathrm{~N}_{2} \mathrm{OF}_{3} \mathrm{Cl}_{2}$ & $\mathrm{C}_{14} \mathrm{H}_{10} \mathrm{~N}_{2} \mathrm{OF}_{3} \mathrm{I}$ & $\mathrm{C}_{30} \mathrm{H}_{30} \mathrm{Cl}_{4} \mathrm{~N}_{6} \mathrm{O}_{8} \mathrm{~S}_{2}$ & $\mathrm{C}_{15.68} \mathrm{H}_{15.67} \mathrm{Cl}_{2} \mathrm{~N}_{3.68} \mathrm{O}_{4} \mathrm{~S}_{0.31}$ & $\mathrm{C}_{36} \mathrm{H}_{51} \mathrm{IN}_{4} \mathrm{O}_{5}$ \\
\hline FW & 349.13 & 406.14 & 808.52 & 400.66 & 746.70 \\
\hline $\begin{array}{l}\text { Crystal } \\
\text { System }\end{array}$ & monoclinic & orthorhombic & triclinic & monoclinic & monoclinic \\
\hline $\begin{array}{l}\text { Space } \\
\text { Group }\end{array}$ & $C c$ & $P c a 2_{1}$ & $P-1$ & $P 2_{1} / n$ & $P 2_{1} / n$ \\
\hline $\mathbf{a} / \AA ̊$ & $11.4548(2)$ & $29.971(5)$ & $12.0136(4)$ & $21.6216(9)$ & $8.8751(2)$ \\
\hline $\mathbf{b} / \AA$ & $13.5410(2)$ & $4.5599(7)$ & $12.6801(4)$ & $3.8114(1)$ & $22.2235(3)$ \\
\hline c/Å & $9.0285(2)$ & $10.4038(14)$ & $13.8642(5)$ & $22.9689(10)$ & $18.3822(3)$ \\
\hline$\alpha /^{\circ}$ & 90 & 90 & $65.778(3)$ & 90 & 90 \\
\hline
\end{tabular}




\begin{tabular}{|l|c|c|c|c|c|}
\hline $\boldsymbol{\beta} /{ }^{\mathbf{0}}$ & $92.4156(16)$ & 90 & $72.336(3)$ & $115.885(5)$ & $92.239(2)$ \\
\hline $\boldsymbol{\gamma} / /^{\mathbf{0}}$ & 90 & 90 & $66.334(3)$ & 90 & 90 \\
\hline $\boldsymbol{V} / \boldsymbol{\AA}^{\mathbf{3}}$ & $1399.16(4)$ & $1421.8(4)$ & $1739.57(12)$ & 1702.94 & $3622.9(1)$ \\
\hline $\boldsymbol{T} / \mathbf{K}$ & $120(2)$ & $120(2)$ & $120(2)$ & $120(2)$ & $120(2)$ \\
\hline $\boldsymbol{Z}$ & 4 & 4 & 2 & 4 & 4 \\
\hline
\end{tabular}

A summary of unit cell parameters and main crystallographic data for the set of crystal structures collected is shown in Table 1. Details of crystallization experiments, intermolecular interactions and crystal packing descriptions are reported in Supporting Information.

Considering the urea molecular unit, the comparison of the molecular conformation for the ten crystal structures shows that in all the structures, urea $\mathrm{NH}$ groups are oriented trans with respect to the carbonyl group, confirming the behaviour generally observed in crystal structures of urea derivatives. Furthermore, in most of them, both phenyl rings are slightly tilted with respect the plane of the urea function (Table 2). The only exception is represented by the two solvated forms, $\mathbf{L} 8 \bullet$ DMSO and $\mathbf{L}_{11} \bullet 2 \mathrm{DMSO} \bullet \mathrm{DMF}$, in which the phenyl rings are co-planar with the urea plane. According to previous observations, the planar conformation of the two solvate forms is stabilised by intramolecular $\mathrm{C}-\mathrm{H} \cdots \mathrm{O}$ hydrogen bonds involving the urea $\mathrm{C}=\mathrm{O}$ group and aromatic $\mathrm{CHs}$ of the phenyl groups $(\mathrm{H} \cdots \mathrm{O}$ distances lie in the range $2.20-2.28 \AA$, C $\cdots \mathrm{O}$ distances lie in the range 2.836(3)-2.876(3) $\AA$ ). However, weak intra-molecular C-H...O hydrogen bonds are also observed in most of the structures which adopt a tilted conformation. Excluding $\mathbf{L}_{15}$ and the two polymorphs $\mathbf{L}_{2} \alpha$ and $\mathbf{L}_{2} \boldsymbol{\beta}$, which show intra-molecular interactions only on the substituted ring the structures (see Table S3, Supporting Information) of the free receptors show a set of intramolecular $\mathrm{C}-\mathrm{H} \cdots \mathrm{O}$ interactions with $\mathrm{H} \cdots \mathrm{O}$ distances in the range $2.30-2.58 \AA$ (C $\cdots \mathrm{O}$ distances in the range $2.828(2)-2.958(8)$ 
$\AA$ ). In the case of $\mathbf{L} \mathbf{5}$ this intramolecular interaction is also assisted by a further intramolecular $\mathrm{N}-\mathrm{H} \cdots \mathrm{O}$ hydrogen bond involving one of the urea $\mathrm{NHs}$ and the nitro group in position ortho ( $\mathrm{H} \cdots \mathrm{O}$ distance is $2.24(5) \AA$, N $\cdots \mathrm{O}$ distance is $2.935(4) \AA$ ). Interestingly, $\mathbf{L 6}_{\mathbf{6}} \mathbf{B z O}^{-}$, adopts a conformation with the phenyl rings tilted out with respect the urea plane, showing only one $\mathrm{C}-\mathrm{H} \cdots \mathrm{O}$ intramolecular interaction involving the $\mathrm{CH}$ in the ortho position on the iodo-substituted ring and the $\mathrm{C}=\mathrm{O}$ of the urea group

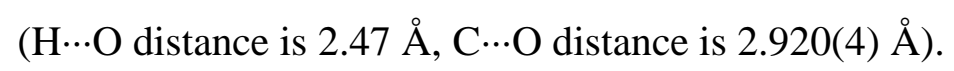

Table 2. Torsion angles $\tau_{1}$ and $\tau_{2}$

\begin{tabular}{|c|c|c|c|c|}
\hline & $\overline{\tau_{1}}$ & $\tau_{2}$ & $\tau_{1},{ }^{*}$ & $\tau_{2}, *$ \\
\hline $\mathbf{L}_{1}$ & $-42.8(3)$ & $38.1(3)$ & - & - \\
\hline $\mathbf{L}_{2} \alpha$ & $-49.1(8)$ & $43.5(8)$ & $-52.9(8)$ & $-54.4(7)$ \\
\hline $\mathbf{L}_{2} \boldsymbol{\beta}$ & $-43.1(5)$ & $56.1(5)$ & & \\
\hline $\mathbf{L}_{5}$ & $-41.2(3)$ & $35.6(3)$ & - & - \\
\hline $\mathbf{L}_{11} \cdot 2 \mathrm{DMSO} \cdot \mathrm{DMF}$ & $-2.1(4)$ & $0.5(4)$ & - & - \\
\hline L8 & $-28.3(3)$ & $23.1(3)$ & - & - \\
\hline $\mathbf{L}_{8} \cdot \mathrm{DMSO}$ & $-3.9(4)$ & $7.5(4)$ & $-3.5(4)$ & $9.7(4)$ \\
\hline $\mathbf{L}_{14}$ & $-22.6(8)$ & $27.4(7)$ & - & - \\
\hline $\mathbf{L}_{15}$ & $-43(3)$ & $44(3)$ & - & - \\
\hline $\mathrm{L}_{6}-\mathrm{BzO}^{-}$ & $-41.9(4)$ & $38.5(4)$ & - & - \\
\hline
\end{tabular}

* For crystal structures with $Z^{\prime}=2$ we use $\tau_{1}$ ' and $\tau_{2}$ ' to indicate torsional angles for the second symmetrically independent molecule.

Most of the structures show the classical 1-D chains connected by three-centre $\mathrm{N}-\mathrm{H} \cdots \mathrm{O}$ hydrogen bonds involving the urea group. Only $\mathbf{L 6}_{6}-\mathbf{B z O}^{-}, \mathbf{L s}^{\bullet} \mathrm{DMSO}$ and 
L11 $\bullet 2$ DSO $\bullet$ DMF adopt alternative supramolecular synthons. In these structures, the presence of the guest molecule with a set of competing hydrogen bond acceptors prevents the formation of the typical urea-urea $\mathrm{N}-\mathrm{H} \cdots \mathrm{O}$ tapes. Accordingly, we discuss separately the three structures $\mathbf{L}_{8} \bullet$ DMSO, $\mathbf{L}_{\mathbf{1 1}} \bullet 2 \mathrm{DMSO} \bullet \mathrm{DMF}$ and $\mathbf{L}_{\mathbf{6}}-\mathbf{B z O}^{-}$and start our discussion focusing on the supramolecular features of free receptors.

\section{One-dimensional N-H $\cdots O$ chains.}

Structures of free receptors show 1-D urea chains, in most cases connected by the robust bifurcated $\mathrm{N}-\mathrm{H} \cdots \mathrm{O}$ supramolecular synthon $(\mathrm{H} \cdots \mathrm{O}$ distances are in the range 1.95-2.70 $\AA$, N...O distances are in the range 2.775(2)-3.406(6) $\AA$ ). The shape of the 1-D chains is very similar in all the structures, consisting of linear arrangements of molecules. The only exceptions are $\mathbf{L}_{\mathbf{1}}$ and $\mathbf{L}_{\mathbf{1 4}}$ in which the chains adopt a zig-zag motif (Fig 1 a and f). In the case of $\mathbf{L}_{\mathbf{1}}$ the phenyl groups within the urea molecule are oriented approximately perpendicular to each other with aromatic hydrogens pointing toward the centre of the phenyl rings of adjacent urea units and forming T-shaped edge-to -face interactions ${ }^{8 \mathrm{~b}}$

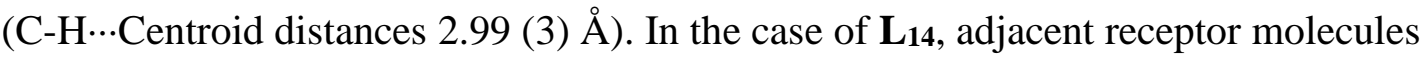
are slightly tilted along the direction of propagation of the 1-D chain. As a consequence, the $\mathrm{N}-\mathrm{H} \cdots \mathrm{O}$ hydrogen bond involves only one of the urea $\mathrm{NH}$ moieties (Fig $1 \mathrm{f}$ ). A similar interaction is observed in $\mathbf{L s}$ (Fig 1 e) but in this case the 1-D urea chain adopts a linear shape. 


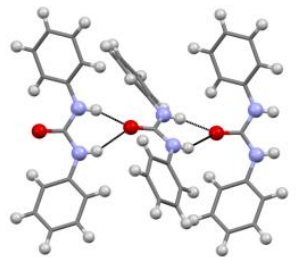

(a)

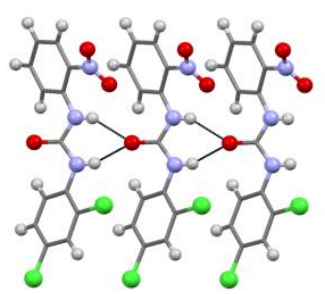

(d)

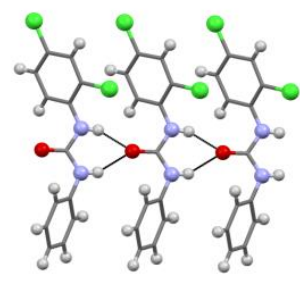

(b)

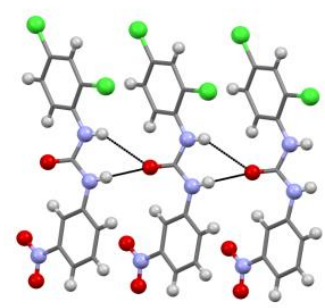

(e)

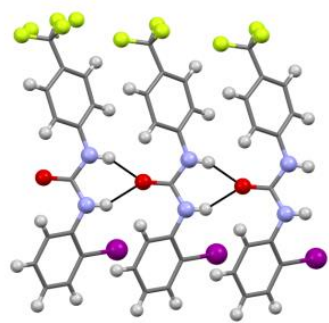

(g)

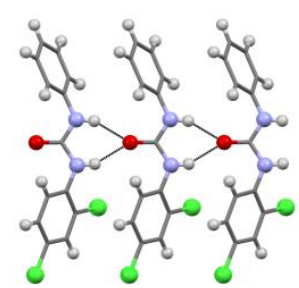

(c)

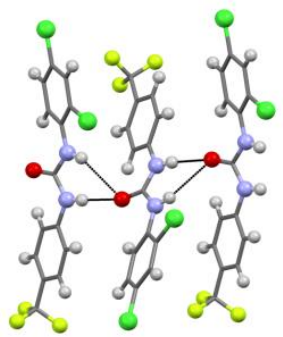

(f)

Fig 1. Ball and stick images of the one-dimensional urea chains for structures of free receptors: (a) $\mathbf{L}_{\mathbf{1}}$; (b) $\mathbf{L}_{\mathbf{2} \alpha}$; (c) $\mathbf{L}_{\mathbf{2} \beta}$; (d) $\mathbf{L}_{5}$; (e) $\mathbf{L} \mathbf{8}$; (f) $\mathbf{L}_{\mathbf{1 4}}$ and (g) $\mathbf{L}_{15}$. For structure $\mathbf{L}_{\mathbf{2} \alpha}$ only one independent molecule is reported as representative of the shape of onedimensional urea chains. $\mathrm{N}-\mathrm{H} \cdots \mathrm{O}$ hydrogen bonds are indicated using black dashed lines; atoms of iodine in purple, chlorine in dark green, fluorine in green/yellow, nitrogen in blue, oxygen in red hydrogen in white and the carbon scaffold in grey. Other interactions have been removed for clarity.

Contrary previous studies, ${ }^{7}$ while the substitution at the phenyl rings introduces potential competing groups with respect to hydrogen bonding, no such competition is observed in the free receptors reported herein. However, in the case of $\mathbf{L} \mathbf{8}$, the urea NHs are also involved in the formation of a further $\mathrm{N}-\mathrm{H} \cdots \mathrm{O}$ interaction (Fig 2 a) with the 
$\mathrm{NO}_{2}$ groups in position meta of adjacent 1-D chains ( $\mathrm{H} \cdots \mathrm{O}$ distance are $2.42 \AA$ and 2.44 $\AA$, N...O distance are 3.142(2) $\AA$ and 3.145(2) $\AA$ ). This particular supramolecular synthon is not observed in the case of the substituted $o-\mathrm{NO}_{2}$ receptor $\mathbf{L} \mathbf{5}$, which, instead forms centro-symmetric dimers with aromatic hydrogens of an adjacent urea unit via C$\mathrm{H} \cdots \mathrm{O}$ interactions (Fig 2 b). In the case of $\mathbf{L} \mathbf{1 5}$, the urea $\mathrm{C}=\mathrm{O}$ group is involved in a second interaction (Fig 2 c) with the iodo substituents of adjacent chains [I...O distance is 3.50 (2) $\AA$ ]. No such behaviour was observed in the crystal structure published by Koshti et al., ${ }^{5 \mathrm{e}}$ which corresponds to our receptor $\mathbf{L} 3$, where the iodo- substituents only

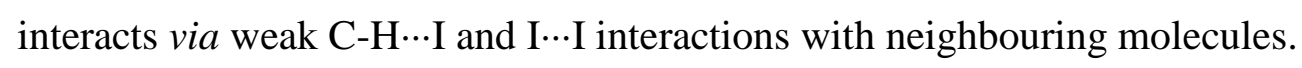

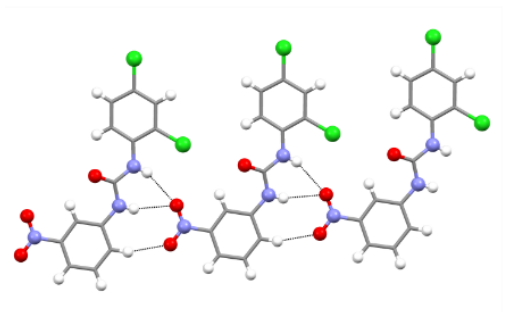

(a)

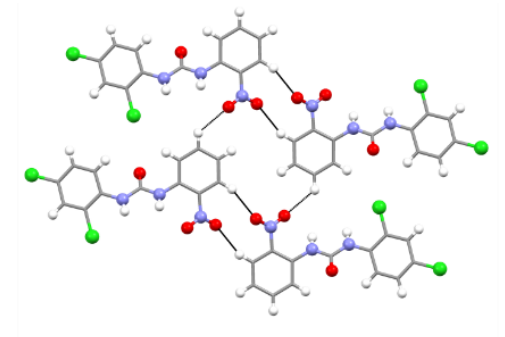

(b)

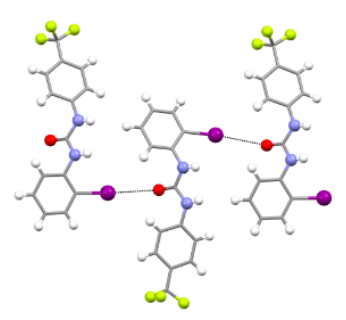

(c)

Fig 2. Further intermolecular interactions for Ls (a), Ls (b) and $\mathbf{L} 15$ (c).

The effect of varying the substituent groups, particularly the set of electron-withdrawing groups chosen for the design of receptors $\mathbf{L}_{\mathbf{1}}-\mathbf{L}_{\mathbf{1 5}}$, seems to have no consistent effect on the strength of the $\mathrm{N}-\mathrm{H} \cdots \mathrm{O}$ hydrogen bonds. Bond length analysis of the $\mathrm{N}-\mathrm{H} \cdots \mathrm{O}$ intermolecular and weaker C-H...O intra-molecular interaction (see Table S3 in Supporting Information) reveals that for structures $\mathbf{L}_{1}, \mathbf{L}_{2} \alpha, \mathbf{L}_{2} \boldsymbol{\beta}, \mathbf{L}_{\mathbf{5}}$ and $\mathbf{L}_{15}$ these are very similar, with $\mathrm{N}-\mathrm{H} \cdots \mathrm{O}$ and $\mathrm{C}-\mathrm{H} \cdots \mathrm{O}$ distances in the range $1.95-2.24 \AA$ and 2.44 $2.58 \AA$, respectively (N...O distances in the range $2.775(2)-2.935(4) \AA ;$ C ... distances in the range 2.881(3)-2.958(8) $\AA$ ). In the case of $\mathbf{L s}$ and $\mathbf{L} \mathbf{1 4}$, when compared to $\mathbf{L} 1$, the presence of electron-withdrawing groups at the phenyl rings slightly increases the 
strength of the intra-molecular $\mathrm{C}-\mathrm{H} \cdots \mathrm{O}$ interactions, with $\mathrm{H} \cdots \mathrm{O}$ distances decrease from the range 2.44-2.53 $\AA$ for $\mathbf{L}_{\mathbf{1}}$ to $2.30-2.40 \AA$ for $\mathbf{L} \mathbf{8}$ and $\mathbf{L}_{\mathbf{1 4}}$ (range of C…O distances decrease from 2.881(3)- 2.973(3) $\AA$ for $\mathbf{L} 1$ to 2.828(2)-2.920(7) $\AA$ for L8 and L14).

\section{Solvates and receptor-anion structures.}

Crystallisation of receptors $\mathbf{L}_{\mathbf{6}}, \mathbf{L}_{\mathbf{8}}$ and $\mathbf{L}_{\mathbf{1 1}}$ in the presence of guest molecules such as solvents or anions produced two solvates forms, $\mathbf{L} 8 \bullet$ DMSO and $\mathbf{L} 11 \cdot 2 \mathrm{DMSO} \bullet \mathrm{DMF}$, corresponding to a DMSO and a DMSO/DMF solvate respectively and one benzoate complex of the receptor $\mathbf{L}_{6}$, labelled as $\mathbf{L}_{6}-\mathbf{B z O}^{-}$.

As mentioned above, in the solvate compounds, the urea units adopt a conformation with the phenyl rings approximately coplanar with the urea plane forming short intramolecular $\mathrm{C}-\mathrm{H} \cdots \mathrm{O}$ interactions. This is a result of the increased acidity of the aromatic hydrogens due to the presence of the electron-withdrawing groups. Previous studies, ${ }^{5 c, 5 d, 6}$ have proposed that, in such case, the urea $\mathrm{C}=\mathrm{O}$ is made a weaker hydrogen bond acceptor and the urea $\mathrm{NH}$ groups preferentially interact with solvent molecules instead, thus disrupting the 1-D urea-urea assemblies.

Structure $\mathbf{L} 8 \bullet$ DMSO crystallises with two independent receptors in the asymmetric unit. These interact with each other via $\mathrm{C}-\mathrm{H} \cdots \mathrm{Cl}$ and $\mathrm{C}-\mathrm{H} \cdots \mathrm{O}$ interactions $(\mathrm{H} \cdots \mathrm{Cl}$ distances are $2.79 \AA$ and $2.92 \AA, \mathrm{C} \cdots \mathrm{Cl}$ distances are 3.696(2) $\AA$ and 3.854(2) $\AA$; H $\cdots \mathrm{O}$ distances are $2.46 \AA$ and $2.50 \AA, \mathrm{C} \cdots \mathrm{O}$ distances are 3.244(3) $\AA$ and 3.317(3) $\mathrm{A})$ involving $\mathrm{Cl}$ and $\mathrm{NO}_{2}$ groups in phenyl rings and the aromatic hydrogen in the para position to form a 1D chain (Fig 3). Each independent receptor interacts with a molecule of DMSO via N$\mathrm{H} \cdots \mathrm{O}$ hydrogen bonds involving urea $\mathrm{NHs}(\mathrm{H} \cdots \mathrm{O}$ distances are in the range 1.87-2.25 $\AA$ A, N...O distances are in the range 2.737(3)- 3.037(3) A). Solvent molecules also interact with urea $\mathrm{C}=\mathrm{O}$ via weak $\mathrm{C}-\mathrm{H} \cdots \mathrm{O}$ interactions involving methyl groups of 


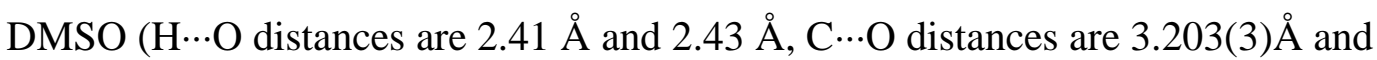
3.383(3) ^). A more detailed description of the crystal packing is reported in Supporting Information.

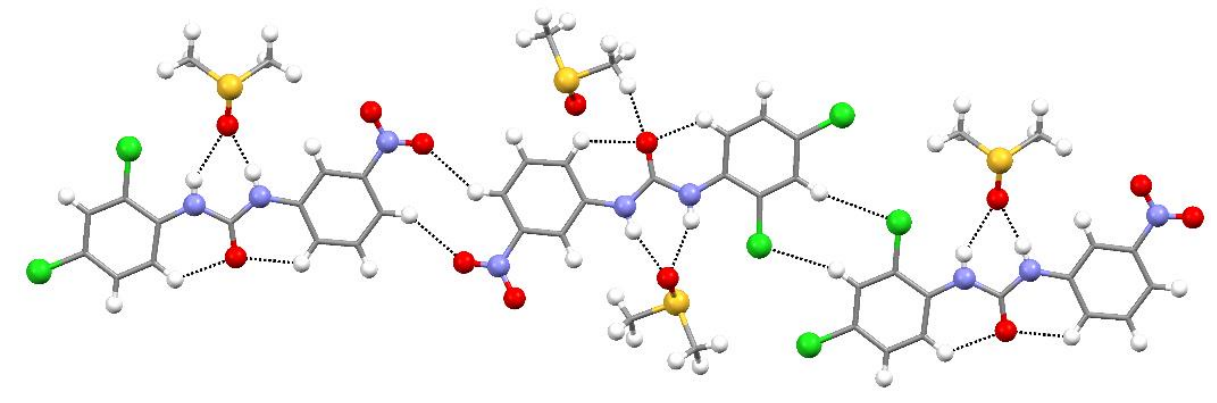

Fig 3. Main intermolecular interaction for structure $\mathbf{L} 8 \bullet$ DMSO.

Structure $\mathbf{L}_{11} \bullet 2 \mathrm{DMSO} \bullet \mathrm{DMF}$ formed a DMSO/DMF solvate with the two solvents disordered to share the same molecular site in a 2:1 ratio, respectively. In this structure, the receptor forms centro-symmetric dimers via $\mathrm{C}-\mathrm{H} \cdots \mathrm{O}$ interactions $(\mathrm{H} \cdots \mathrm{O}$ distance is $2.51 \AA, \mathrm{C} \cdots \mathrm{O}$ distance is $3.337(3) \AA$ ) involving the urea $\mathrm{C}=\mathrm{O}$ group and the aromatic hydrogen in a position meta to the di-chloro substituted phenyl ring (Fig 4). This dimer exposes the urea $\mathrm{NH}$ groups which interact with neighbouring solvent molecules via $\mathrm{N}$ $\mathrm{H} \cdots \mathrm{O}$ hydrogen bonds involving the $\mathrm{S}=\mathrm{O}$ or $\mathrm{C}=\mathrm{O}$ groups, depending on the solvent present. The $\mathrm{H} \cdots \mathrm{O}$ distances are in the range 1.95-2.48 $\AA$ ( $\mathrm{N} \cdots \mathrm{O}$ distances are in the range 2.801(5)- 3.226(12) A). Receptor molecules interact along the shortest axis of the unit cell via $\pi \cdots \pi$ stacking (centroid-centroid.distance 3.811(1) $\AA$ ). A detailed description of the crystal packing is reported in Supporting Information. 


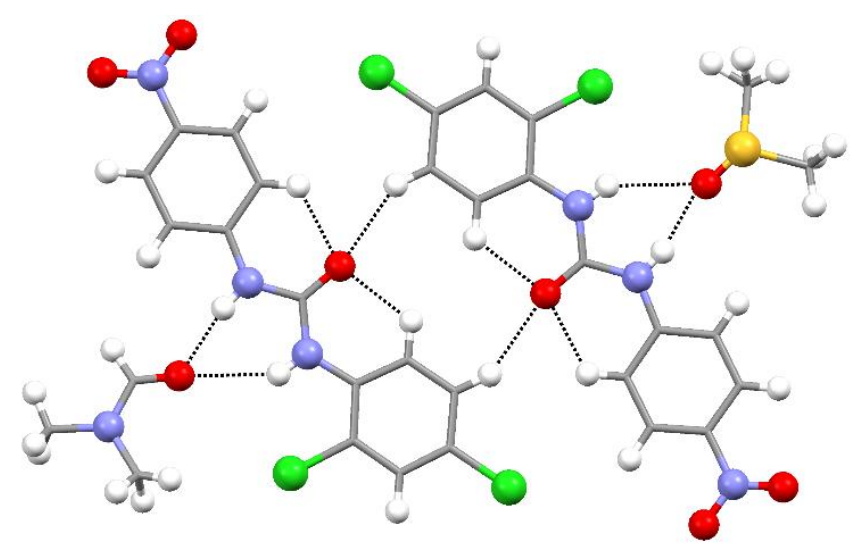

Fig 4. Main intermolecular interactions for structure $\mathbf{L}_{\mathbf{1 1}} \bullet 2 \mathrm{DMSO} \bullet \mathrm{DMF}$. DMSO and DMF have been separated for clarity.

In the adduct $\mathbf{L 6}_{6}-\mathrm{BzO}^{-}$the urea $\mathrm{NH}$ groups are involved in the formation of strong $\mathrm{N}$ $\mathrm{H} \cdots \mathrm{O}$ hydrogen bonds with the $\mathrm{BzO}^{-}$guest $(\mathrm{H} \cdots \mathrm{O}$ distances are $1.92(4) \AA$ and $2.10(4) \AA$, N...O distances are $2.717(3) \AA$ and 2.878(3) $\mathrm{A})$. Interestingly, in this case the receptor molecule has a non-planar conformation with the phenyl rings slightly tilted with respect the urea plane. Accordingly, no intramolecular $\mathrm{C}-\mathrm{H} \cdots \mathrm{O}$ interactions are observed between the urea $\mathrm{C}=\mathrm{O}$ group and aromatic $\mathrm{CHs}$ in the ortho positions of the phenyl rings. This can be explained considering that in order to have a planar conformation stabilised by intramolecular $\mathrm{C}-\mathrm{H} \cdots \mathrm{O}$ interactions, the receptor must have the substituted group in an ortho position and, both on the same side of the urea NHs. Such a case would present significant steric hindrance or electronic repulsion towards the anionic guest. Accordingly, the best compromise seems to be a tilted conformation with the I and $\mathrm{NO}_{2}$ group oriented mutually trans and the $\mathrm{NO}_{2}$ group on the opposite side with respect the urea NHs. As a consequence of this conformation, in order to interact with the receptor site, minimising the repulsion of the iodo substituent, the $\mathrm{BzO}^{-}$ specie is slightly shifted on the side of the nitro-phenyl ring, using one oxygen of the carboxylate group to interact with the two urea $\mathrm{NH}$ donors through a bifurcated $\mathrm{N}-\mathrm{H} \cdots \mathrm{O}$ 
hydrogen bond. The second oxygen forms a $\mathrm{C}-\mathrm{H} \cdots \mathrm{O}$ interaction with one aromatic $\mathrm{CH}$ of the nitro-phenyl ring ( $\mathrm{H} \cdots \mathrm{O}$ distance is $2.46 \AA$, C $\cdots \mathrm{O}$ distance is 3.364(4) $\AA$, see Fig 5)

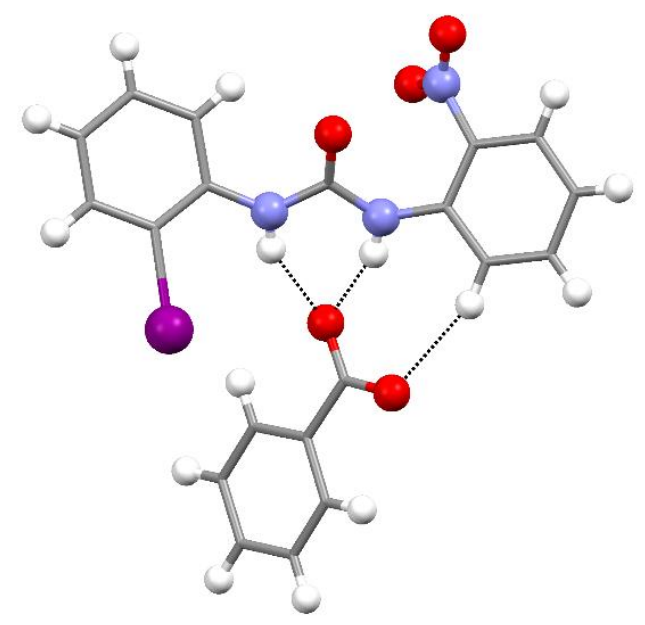

Fig 5. Receptor-anion interaction and conformation of receptor $\mathbf{L}_{\mathbf{6}}$ in crystal structure of L6-BzO-. Countercation has been omitted for clarity.

\section{Solution studies}

Anion binding affinity of receptors $\mathbf{L}_{1}-\mathbf{L}_{15}$ was evaluated by means of ${ }^{1} \mathrm{H}-\mathrm{NMR}$ titrations in DMSO- $d_{6} / 0.5 \% \mathrm{H}_{2} \mathrm{O}$ towards a set of anions $\left(\mathrm{F}^{-}, \mathrm{Cl}^{-}, \mathrm{H}_{2} \mathrm{PO}_{4}^{-}, \mathrm{AcO}^{-}\right.$, and $\mathrm{BzO}^{-}$, as their tetrabutylammonium salts). The experimental data were fitted according to a 1:1 model and the stability constants (Table 3) were calculated using the WINEQNMR programme. ${ }^{13}$

By means of a COSY (Correlation Spectroscopy) 2D-NMR experiment it was possible to attribute the correct chemical shift value for each $\mathrm{NH}$ proton in the asymmetrical receptors $\mathbf{L}_{2}$ and $\mathbf{L}_{3}$ (and therefore for all the other halogenated receptors): the $\mathrm{NH}$ proton in close proximity of the phenyl moiety is downfield shifted with respect to the NH protons near the 2,4-dichloro phenyl and the 2-iodophenyl fragments for $\mathbf{L}_{\mathbf{2}}$ and $\mathbf{L}_{3}$, respectively. 
Stability constants calculated following both $\mathrm{NH}$ proton signals were comparable so we decided to follow the chemical shift of the NH proton signal in close proximity of the non-halogenated phenyl ring.

The results observed for the triad $\mathbf{L}_{1}, \mathbf{L}_{2}, \mathbf{L}_{\mathbf{3}}$ are in agreement with the degree of steric hindrance increasing in the order $\mathbf{L}_{\mathbf{3}}>\mathbf{L}_{\mathbf{2}}>\mathbf{L}_{\mathbf{1}}$. The presence of the chlorine or iodine atom in an ortho position on the halogenated phenyl ring with respect to the urea function, for $\mathbf{L}_{\mathbf{2}}$ and $\mathbf{L} \mathbf{3}$, respectively, partially obstructs the anion access to the coordination site of the receptor. Several anion binding studies for receptor $\mathbf{L}_{1}$ are reported in the literature, in particular recognition of carboxylates. ${ }^{12 b, 14}$ The stability constants obtained for the formation of the 1:1 adduct of $\mathbf{L}_{\mathbf{1}}$ with acetate and benzoate at $300 \mathrm{~K}$ are consistent with the values reported by Leito et al. at $298 \mathrm{~K}\left(2138 \mathrm{M}^{-1}\right.$ and 661 $\mathrm{M}^{-1}$ for acetate and benzoate, respectively).

Table 3. Stability constants $\left(K_{\mathrm{a}} / \mathrm{M}^{-1}\right)$ of the 1:1 adducts of $\mathbf{L} \mathbf{1}-\mathbf{L} \mathbf{1 5}$ with $\mathrm{F}^{-}, \mathrm{Cl}^{-}, \mathrm{H}_{2} \mathrm{PO}_{4}^{-}$, $\mathrm{AcO}^{-}, \mathrm{BzO}^{-}$, as their tetrabutylammonium salts in DMSO- $d_{6} / 0.5 \% \mathrm{H}_{2} \mathrm{O}$ at $300 \mathrm{~K}$.

\begin{tabular}{cccccc}
\hline Receptor & $\mathbf{H}_{2} \mathbf{P O}_{4}{ }^{-}$ & $\mathbf{C l}^{-}$ & $\mathbf{F}^{-}$ & $\mathbf{A c O}^{-}$ & \\
\hline
\end{tabular}



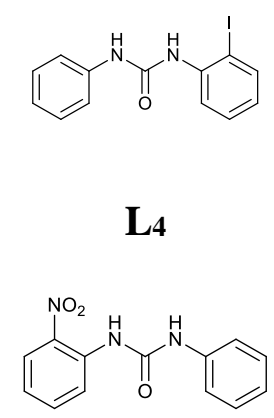
$684 \pm \quad<10 \quad$ Deprot. $^{\mathrm{b}} \quad 1283 \pm 3.5 \% \quad 314 \pm$
$5.9 \% \quad 5.9 \%$

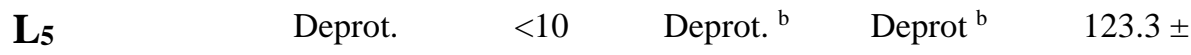

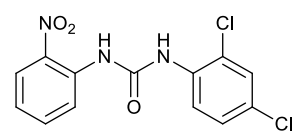

$5.9 \%$

L6<smiles>Cc1ccccc1NC(=O)Nc1ccccc1[N+](=O)[O-]</smiles>

$\mathbf{L}_{7}$<smiles>O=C(Nc1ccccc1)Nc1cccc([N+](=O)[O-])c1</smiles>

L8<smiles>O=C(Nc1cccc([N+](=O)[O-])c1)Nc1ccc(Cl)cc1Cl</smiles>

L9<smiles>O=C(Nc1cccc([N+](=O)[O-])c1)Nc1ccccc1I</smiles>

L10<smiles>O=C(Nc1ccccc1)Nc1ccc([N+](=O)[O-])cc1</smiles>

$\mathbf{L} 11$
$<10 \quad$ Deprot. $^{\mathrm{b}} \quad 218.0 \pm 3.9 \% \quad 87.3 \pm$ $11.0 \%$

$57.8 \pm \quad$ Deprot. $^{\mathrm{b}} \quad 9620 \pm 3.8 \% \quad 3322 \pm$

$1.8 \%-1.8 \%$

$35.2 \pm \quad$ Deprot. $^{\mathrm{b}} \quad 1883 \pm 8 \% \quad 567 \pm$

$7.8 \%$

$0.9 \%$

$20.6 \pm \quad$ Deprot. $^{\mathrm{b}} \quad 1611 \pm 4.3 \% \quad 425 \pm$

$2.3 \%$

$2.8 \%$

$68.6 \pm \quad$ Deprot. $^{\text {b }} \quad 13467 \pm \quad 3706 \pm$

$\begin{array}{lll}2.9 \% & 2.3 \% & 1.0 \%\end{array}$

$36.8 \pm \quad$ Deprot. $^{\text {b }} \quad 6833 \pm 30 \% \quad 780 \pm$

$0.7 \%$

$1.7 \%$ 
<smiles>O=C(Nc1ccc([N+](=O)[O-])cc1)Nc1ccc(Cl)cc1Cl</smiles>

$\mathbf{L}_{12}$<smiles>O=C(Nc1ccc([N+](=O)[O-])cc1)Nc1ccccc1I</smiles>

$\mathbf{L}_{13}$<smiles>O=C(Nc1ccccc1)Nc1ccc(C(F)(F)F)cc1</smiles>

$\mathbf{L}_{14}$<smiles>O=C(Nc1ccc(F)cc1)Nc1ccc(Cl)cc1Cl</smiles>

L15<smiles>O=C(Nc1ccc(C(F)(F)F)cc1)Nc1ccccc1I</smiles>

$26.2 \pm$

Deprot. $^{b}$

$1470 \pm 5.6 \%$

$681 \pm$

$6.2 \%$

$1.6 \%$

$871.9 \pm \quad 52.2 \pm \quad$ Deprot. $^{\text {b }} \quad 2608 \pm 17 \% \quad 1980 \pm$

a Significant downfield shift and broadening of the signals attributed to the urea NHs suggesting strong interaction.

b Disappearance of the signals attributed to the urea NHs upon addition of 0.1 equivalent of fluoride, suggesting deprotonation.

The slight difference in values is probably due to the difference in the temperature at which the experiments were conducted $(300 \mathrm{~K}$ in our case, and $298 \mathrm{~K}$ for the data reported in the literature).

In the triad $\mathbf{L 4} \mathbf{4} \mathbf{L} 6$, the presence of the nitro group in an ortho position with respect to the central urea function in addition to the presence of the chlorine and iodine atoms in the halogen-substituted phenyl rings, causes a decrease in the calculated stability 
constants values compared to those of $\mathbf{L}_{\mathbf{1}}-\mathbf{L} \mathbf{3}$. This result can be explained in terms of both steric and electronic effects. In the triad $\mathbf{L}_{\mathbf{4}}-\mathbf{L}_{\mathbf{6}}$ the nitro group is in close proximity to the urea function and it could obstruct the anion coordination. $\mathrm{AcO}^{-}$and $\mathrm{H}_{2} \mathrm{PO}_{4}{ }^{-}$cause deprotonation of the receptor $\mathbf{L}_{\mathbf{5}}$, presumably because of a combination of the elctron withdrawing properties of the nitro group in ortho position that increase the acidity of the NH proton, and the steric hindrance that disfavour the anion binding favouring, instead, the competitive deprotonation process in the case of basic anions.

In the series of receptors $\mathbf{L}_{7}-\mathbf{L} \mathbf{9}$ the stability constants increase with respect to the previous triad $\mathbf{L}_{\mathbf{4}}-\mathbf{L}_{6}$, probably due the meta positioning of the nitro group that allows a more favourable interaction between the anions and the urea binding site. The interaction of receptor $\mathbf{L}_{7}$ and anion guests was previously studied by means of UVvisible and ${ }^{1} \mathrm{H}-\mathrm{NMR}$ spectroscopy, ${ }^{12,14}$ and the values of the stability constants reported in Table 1 are in agreement with the literature.

The series of receptors $\mathbf{L 1 0}-\mathbf{L} \mathbf{2}$ shows the highest stability constants among all the receptors bearing a nitro group. In particular, receptor $\mathbf{L} \mathbf{1 0}$, already known in the literature,${ }^{15}$ displays a good affinity for acetate as confirmed by the high value of the stability constant $\left(>10^{4} \mathrm{M}^{-1}\right)$. The reasons for the increasing anion coordinating ability of these receptors could be ascribed to both steric and electronic factors. First, the nitro group in the para position with respect to the active urea, should decrease the steric hindrance observed for the previous triads ( $\left.\mathbf{L}_{\mathbf{4}}-\mathbf{L} \mathbf{9}\right)$ allowing for easier access of the anion in the pseudo-cavity of the receptors also for bigger anion like benzoate. Moreover, an electron- withdrawing nitro group in the para position should influence in a positive way the coordination properties of the ligands, thereby increasing the acidity of the urea NH protons. 
The anion binding activity across this series is consistent with the trends previously described for the other receptors. The stability constants decrease from $\mathbf{L}_{13}$ to $\mathbf{L}_{15}$ because of the varying steric hindrance of the halogen on the phenyl ring. By comparing the stability constant of receptor $\mathbf{L}_{15}$ with that of receptor $\mathbf{L}_{\mathbf{3}}$ (without substituents on the non-halogenated phenyl ring) and receptor $\mathbf{L}_{\mathbf{1 2}}$ (with a nitro group in place of the trifluoromethyl unit), it is possible to define the increasing anion affinity in the order $\mathbf{L}_{3}<$ $\mathbf{L} 15<\mathbf{L 1 2}$. This evidence is in agreement with the lower acidity of the NH protons in the unsubstituted receptor $\mathbf{L}_{3}$ compared to receptors $\mathbf{L}_{15}$ and $\mathbf{L}_{12}$. On the other hand, between receptors $\mathbf{L}_{15}$ and $\mathbf{L}_{12}$, the lower ability of receptor $\mathbf{L}_{15}$ to bind anions can be explained by taking into account the electron- withdrawing nature of the $\mathrm{CF}_{3}$ group with respect to the $\mathrm{NO}_{2}$ group. The same behaviour can be found for the series $\mathbf{L}_{1}-\mathbf{L}_{10}-\mathbf{L}_{13}$ and $\mathbf{L}_{2}-\mathbf{L}_{11}-$ L14. 


\section{Conclusions}

In conclusion, we have described herein the synthesis and the anion binding properties of fifteen $N-N^{\prime}$-diphenylurea receptors substituted with electron-withdrawing groups (namely nitro and trifluoromethyl) and halogens (chlorine and iodine). We were able to obtain crystals suitable for single crystal X-ray diffraction for nine receptors (including two polymorphs and two solvates) and the 1:1 adduct of $\mathbf{L}_{6}$ with benzoate. As expected, the classic urea 1-D chains were observed in most of the structures. Only $\mathbf{L}_{6}-\mathbf{B z O}^{-}$, $\mathbf{L} 8 \bullet$ DMSO and $\mathbf{L}_{\mathbf{1 1}} \bullet 2 \mathrm{DMSO} \bullet$ DMF adopted alternative supramolecular synthons because of the presence of the anion guest or the solvents that prevents the formation of the typical urea-urea $\mathrm{N}-\mathrm{H} \cdots \mathrm{O}$ tapes. Solution studies conducted by means of ${ }^{1} \mathrm{H}-\mathrm{NMR}$ spectroscopic titrations allowed us to calculate the stability constant for the formation of the $1: 1$ adducts with all receptors and a set of anions $\left(\mathrm{F}^{-}, \mathrm{Cl}^{-}, \mathrm{H}_{2} \mathrm{PO}_{4}^{-}, \mathrm{AcO}^{-}, \mathrm{BzO}^{-}\right)$. The highest values of stability constants were obtained for the receptors $\mathbf{L}_{\mathbf{1 0}}-\mathbf{L}_{\mathbf{1 2}}$ bearing the nitro group in the para position with respect to the urea moiety.

\section{Acknowledgements}

The authors thank the financial support from Fondazione Banco di Sardegna.

\section{References}

1. (a) Ashton, T. D.; Jolliffe, K. A.; Pfeffer, F. M., Luminescent probes for the bioimaging of small anionic species in vitro and in vivo. Chemical Society Reviews 2015, 44 (14), 4547-4595; (b) Busschaert, N.; Caltagirone, C.; Van Rossom, W.; Gale, P. A., Applications of Supramolecular Anion Recognition. Chemical Reviews 2015, 115 (15), 8038-8155; (c) Duke, R. M.; Veale, E. B.; Pfeffer, F. M.; Kruger, P. E.; Gunnlaugsson, T., Colorimetric and fluorescent anion sensors: An overview of recent developments in the use of 1,8-naphthalimide-based chemosensors. Chemical Society Reviews 2010, 39 (10), 3936-3953; (d) Gale, P. A.; Caltagirone, C., Fluorescent and colorimetric sensors for anionic species. Coordination Chemistry Reviews; (e) Gale, P. A.; Caltagirone, C., Anion sensing by small molecules and molecular ensembles. Chemical Society Reviews 2015, 44 (13), 4212-4227; (f) Ngo, H. T.; Liu, X.; Jolliffe, K. A., Anion recognition and sensing with $\mathrm{Zn}$ (ii)-dipicolylamine complexes. Chemical Society Reviews 2012, 41 (14), 4928-4965. 
2. (a) Casula, A.; Bazzicalupi, C.; Bettoschi, A.; Cadoni, E.; Coles, S. J.; Horton, P. N.; Isaia, F.; Lippolis, V.; Mapp, L. K.; Marini, G. M.; Montis, R.; Scorciapino, M. A.; Caltagirone, C., Fluorescent asymmetric bis-ureas for pyrophosphate recognition in pure water. Dalton Transactions 2016, 45 (7), 3078-3085; (b) Amendola, V.;

Bonizzoni, M.; Esteban-Gómez, D.; Fabbrizzi, L.; Licchelli, M.; Sancenón, F.; Taglietti, A., Some guidelines for the design of anion receptors. Coordination Chemistry Reviews 2006, 250 (11-12), 1451-1470; (c) Antonisse, M. M. G.; Reinhoudt, D. N., Neutral anion receptors: Design and application. Chemical Communications 1998, (4), 443448; (d) Gale, P. A., Structural and molecular recognition studies with acyclic anion receptors. Accounts of Chemical Research 2006, 39 (7), 465-475; (e) Hay, B. P.; Firman, T. K.; Moyer, B. A., Structural design criteria for anion hosts: Strategies for achieving anion shape recognition through the complementary placement of urea donor groups. Journal of the American Chemical Society 2005, 127 (6), 1810-1819; (f) Li, A. F.; Wang, J. H.; Wang, F.; Jiang, Y. B., Anion complexation and sensing using modified urea and thiourea-based receptors. Chemical Society Reviews 2010, 39 (10), 3729-3745; (g) Nishizawa, S.; Bühlmann, P.; Iwao, M.; Umezawa, Y., Anion recognition by urea and thiourea groups: Remarkably simple neutral receptors for dihydrogenphosphate. Tetrahedron Letters 1995, 36 (36), 6483-6486.

3. Casula, A.; Llopis-Lorente, A.; Garau, A.; Isaia, F.; Kubicki, M.; Lippolis, V.; Sancenón, F.; Martínez-Máñez, R.; Owczarzak, A.; Santi, C.; Andrea Scorciapino, M.; Caltagirone, C., A new class of silica-supported chromo-fluorogenic chemosensors for anion recognition based on a selenourea scaffold. Chemical Communications 2017, 53 (26), 3729-3732.

4. Blažek Bregović, V.; Basarić, N.; Mlinarić-Majerski, K., Anion binding with urea and thiourea derivatives. Coordination Chemistry Reviews 2015, 295, 80-124.

5. (a) Capacci-Daniel, C. A.; Bertke, J. A.; Dehghan, S.; Hiremath-Darji, R.; Swift, J. A., Concomitant polymorphs of 1,3-bis(3-fluorophenyl)urea. Acta Crystallographica Section C 2016, 72 (9), 692-696; (b) Custelcean, R., Crystal engineering with urea and thiourea hydrogen-bonding groups. Chemical Communications 2008, (3), 295-307; (c) Deshapande, S. V.; Meredith, C. C.; Pasternak, R. A., Crystallographic data on disubstituted symmetric ureas. Acta Crystallographica Section B 1968, 24 (10), 13961397; (d) Etter, M. C., Hydrogen bonds as design elements in organic chemistry. Journal of Physical Chemistry 1991, 95 (12), 4601-4610; (e) Koshti, V. S.; Thorat, S. H.; Gote, R. P.; Chikkali, S. H.; Gonnade, R. G., The impact of modular substitution on crystal packing: the tale of two ureas. CrystEngComm 2016, 18 (37), 7078-7094; (f) Taouss, C.; Thomas, L.; Jones, P. G., Packing principles for urea and thiourea solvates: structures of urea : morpholine $(1: 1)$, urea : 1,4-dioxane $(1: 1)$, thiourea : morpholine (4:3) and thiourea : 1,4-dioxane (4 : 1). CrystEngComm 2013, 15 (34), 6829-6836.

6. (a) Etter, M. C.; Panunto, T. W., 1,3-Bis(m-nitrophenyl)urea: An exceptionally good complexing agent for proton acceptors. Journal of the American Chemical Society 1988, 110 (17), 5896-5897; (b) Etter, M. C.; Urbañczyk-Lipkowska, Z.; Zia-Ebrahimi, M.; Panunto, T. W., Hydrogen bond directed cocrystallization and molecular recognition properties of diarylureas. Journal of the American Chemical Society 1990, 112 (23), 8415-8426.

7. Reddy, L. S.; Chandran, S. K.; George, S.; Babu, N. J.; Nangia, A., Crystal structures of N-aryl-N'-4-nitrophenyl ureas: Molecular conformation and weak interactions direct the strong hydrogen bond synthon. Crystal Growth and Design 2007, 7 (12), 2675-2690.

8. (a) Kirby, I. L.; Brightwell, M.; Pitak, M. B.; Wilson, C.; Coles, S. J.; Gale, P. A., Systematic experimental charge density analysis of anion receptor complexes. 
Physical Chemistry Chemical Physics 2014, 16 (22), 10943-10958; (b) Kirby, I. L.; Pitak, M. B.; Wenzel, M.; Wilson, C.; Sparkes, H. A.; Coles, S. J.; Gale, P. A., Systematic structural analysis of a series of anion receptor complexes. CrystEngComm 2013, 15 (44), 9003-9010.

9. $\quad$ Desiraju, G. R.; Shing Ho, P.; Kloo, L.; Legon, A. C.; Marquardt, R.; Metrangolo, P.; Politzer, P.; Resnati, G.; Rissanen, K., Definition of the halogen bond (IUPAC recommendations 2013). Pure and Applied Chemistry 2013, 85 (8), 17111713.

10. Chudzinski, M. G.; McClary, C. A.; Taylor, M. S., Anion receptors composed of hydrogen- and halogen-bond donor groups: Modulating selectivity with combinations of distinct noncovalent interactions. Journal of the American Chemical Society 2011, 133 (27), 10559-10567.

11. Chutia, R.; Das, G., Hydrogen and halogen bonding in a concerted act of anion recognition: $\mathrm{F}$ - induced atmospheric $\mathrm{CO}<\mathrm{inf}>2</ \mathrm{inf}>$ uptake by an iodophenyl functionalized simple urea receptor. Dalton Transactions 2014, 43 (41), 15628-15637. 12. (a) Baggi, G.; Boiocchi, M.; Ciarrocchi, C.; Fabbrizzi, L., Enhancing the anion affinity of urea-based receptors with a Ru(terpy) 22+ chromophore. Inorganic Chemistry 2013, 52 (9), 5273-5283; (b) Kadam, S. A.; Haav, K.; Toom, L.; Haljasorg, T.; Leito, I., NMR method for simultaneous host-guest binding constant measurement. Journal of Organic Chemistry 2014, 79 (6), 2501-2513.

13. Hynes, M. J., EQNMR: A computer program for the calculation of stability constants from nuclear magnetic resonance chemical shift data. Journal of the Chemical Society, Dalton Transactions 1993, (2), 311-312.

14. Kadam, S. A.; Martin, K.; Haav, K.; Toom, L.; Mayeux, C.; Pung, A.; Gale, P. A.; Hiscock, J. R.; Brooks, S. J.; Kirby, I. L.; Busschaert, N.; Leito, I., Towards the Discrimination of Carboxylates by Hydrogen-Bond Donor Anion Receptors. Chemistry - A European Journal 2015, 21 (13), 5145-5160.

15. Ghosh, A.; Jose, D. A.; Das, A.; Ganguly, B., A density functional study towards substituent effects on anion sensing with urea receptors. Journal of Molecular Modeling 2010, 16 (9), 1441-1448. 